\title{
Hubungan tingkat kecemasan terhadap performance atlet dayung Traditional Boat Race (TBR)
}

\section{Correlation between anxiety levels and performance of Traditional Boat Race (TBR) athletes}

\author{
Deswita Supriyatni ${ }^{1}$, Rony M Rizal ${ }^{2}$, Ridhwan M Rasyad ${ }^{3}$ \\ ${ }^{1,2,3}$ Program studi PJKR, STKIP Pasundan, Cimahi, Jawa Barat, 40512, Indonesia
}

\begin{abstract}
Abstrak
penelitian ini bertujuan untuk mencari hubungan tingkat kecemasan terhadap performance atlet dayung Tradisional Boat Race (TBR) Club Dayung Three Generation. penelitian ini menggunakan metode survey dengan pendekatan kuantitatif. Dengan sample sebanyak 16 orang atlet dayung Tradisional Boat Race (TBR) Club Dayung Three Generation. Instrumen yang digunakan adalah kuesioner kecemasan dan kuesioner peak performance. Analisis data menggunakan teknik analisis regresi sederhana dengan SPSS. Hasil penelitian ini menunjukan bahwa hubungan antara kecemasan terhadap performance (koefisien regresi sebesar -0,688 dan nilai signifikasi sebesar 0,003). Hal ini berarti bahwa semakin tinggi tingkat kecemasan maka semakin rendah tingkat performance pada atlet. Kontribusi yang diberikan kecemasan terhadap performance sebesar $47.4 \%$ sedangkan $52.6 \%$ dipengaruhi oleh faktor lain.
\end{abstract}

Kata kunci: kecemasan, performance, dayung

\begin{abstract}
This study aims to search correlation of anxiety level to the performance of the Traditional Rowing Boat Race (TBR) Club Paddle Three Generation Club. This research uses survey method with quantitative approach. With a sample of 16 traditional rowing boat race (TBR) Three Rowing Club athletes. The instruments used were anxiety questionnaire and peak performance questionnaire. Data analysis using simple regression analysis techniques with SPSS. The results of this study indicate that the relationship between anxiety and performance (regression coefficient of -0.668 and significance value of 0.003). This means that the higher the level of anxiety, the lower the level of performance in athletes. The contribution of anxiety given to the performance was $47.4 \%$ while $52.6 \%$ was influenced by other factors.
\end{abstract}

Keywords: anxiety, performance, rowing, paddle

\section{PENDAHULUAN}

Olahraga merupakan suatu aktivitas dalam kehidupan manusia. Olahraga yang dilakukan secara rutin dan tepat akan membuat manusia menjadi sehat dan kuat, baik jasmani dan rohani. olahraga di indonesia kini semakin berkembang dibuktikan dengan banyaknya olahraga beregu atau pun individu. Salah satunya olahraga yang berkembang di indonesia adalah olahraga dayung. Olahraga dayung adalah olahraga yang dilakukan dengan menggunakan media air, perahu, dan dayung. Menurut (Zuzana, 2015) olahraga

Correspondence author: Deswita Supriatni/Roni M Rizal/ Ridhwan M Rasyad STKIP Pasundan, Indonesia. 
dayung sudah ada sejak manusia mengenal air dan perahu. Oleh sejak itu terdapat berbagai jenis perahu dan bentuk perahu di belahan bumi. Dayung moderen berasal dari sejarah orang-orang kaya dan pangeran di inggris yang tinggal di luar kota. Untuk pergi ke kota mereka memakai perahu yang mewah dan di dayung oleh beberapa pedayung (tergantung kekayaan seseorang). Supaya cepat sampai tujuan maka pedayungnya disuruh cepat mendayung perahunya, hal ini yang menjadi cikal bakal perlombaan dayung.

Olahraga Dayung balap perahu naga adalah olahraga air yang berkembang pesat yang berasal dari China lebih dari 2.000 tahun yang lalu. Di wilayah Jawa Barat memiliki banyak club dayung yang salah satunya adalah paguyuban atau Club Dayung Three Generation.Club Dayung Three Generation memiliki banyak prestasi dari mulai tingkat kota/kabupaten sampai nasional, salah satu prestasi yang telah didapat adalah menjuarai kejuaraan Mapala Tapak Giri Unisma tahun 2018 di tingkat nasional serta tidak hanya menjuarai pertandingan. Tetapi banyak atlet $c l u b$ dayung three generation yang menjadi atlet kota/kabupaten sampai atlet nasional. Tahun yang sama pada bulan Desember 2018 club mengalami penurunan prestasi dengan tidak meraih juara pada kejuaraan Fetival Perahu Naga k-4 di Depok dengan mempertandingkan Tradisional Boat Race nomber 12 pedayung. ini terjadi karena adanya beberapa faktor penyebab penurunan performance club.

Menurut hasil wawancara yang dilakukan dengan atlet Club Dayung Three Generation, ada beberapa faktor yang memperngaruhi performance atlet yaitu adanya gangguan psikologi yaitu faktor kecemasan ini disebabkan karena atlet dayung Club Dayung Three Generation yang akan melaksanakan pertandingan mengalami kegugupan, rasa khawatir yang berlebihan, dan stress. Gejala yang dialami atlet tersebut adalah atlet merasakan mual, rasa percaya diri yang menurun, gelisah. Dengan adanya faktor psikologis yang memperngaruhi atlet sebelum pertandingan faktor tersebut akan mempengaruhi performance atlet tersebut yang menyebabkan atlet tidak fokus saat pertandingan, hilangnya teknik mendayung, dan konsentrasi terganggu, kebigungan. Menurut R.S \& Gould, D dalam (Gunarsa,2008)"sport and exercise pschoogy is the scientific study of pople and their behavior in sport and exercise context". Secara garis besar, kegiatannya adalah:

1. Memperlajari bagaimana factor psikologi mempengaruhi penampilan seseorang.

2. Memahami bagaimana keteribatan seseorang dalam olahraga mempengaruhi perkembangan psikis, kesehatan, dan kesejahteraan psikisnya.

Menurut Haruki dalam (Miftah, 2017) dalam salah satu faktor yang 
menyebabkan peak performance adalah faktor yang berhubunngan dengan atlet yaitu kecemasan bertanding. Kartono dalam (Fitri, 2016) bahwa cemas adalah bentuk ketidakberanian ditambah kerisauan terhadap hal-hal yang tidak jelas. (Husdarta, 2010) membedakan faktor kecemasan bisa berasal dari diri atlet, dan bisa juga dari luar. Tekanan selama bermain, serta tingkat stres dan kecemasan yang tinggi, ditransfer ke area emosional, yang dapat menyebabkan penurunan performance.

Berdasarkan latar belakang tersebut, maka peneliti tertarik untuk melakukan penelitian tentang "Hubugan Tingkat Kecemasan Terhadap Performance Atlet Dayung Tradisional Boat Race (TBR) Club Dayung Three Generation”. salah satu alasan peneliti melakukan penelitian ini karena adanya penurunan prestasi Club Dayung Three Generation yang berdasarkan hasil wawancara disebebkan oleh faktor psikologi atau kecemasan.

\section{METODE}

Penelitian ini menggunakan metode survey dengan pendekatan kuantitatif dengan jenis penelitian kolerasi (Arikunto, 2010). Penelitian ini dilakukan di sungai Cisadane Kota Tanggerang, dikarenakan pada tanggal 26-28 Juli 2019 betepatan dengan Festival Cisadane 2019 yang mengadakan Kejuaraan Cisadane Internasional Dragon Boat Tournament 2019.

Dalam penelitian ini populasinya adalah atlet dayung Club Three Generation yang berjumlah 20 orang atlet. Menggunakan sample penelitian teknik sampling purposive sampling. Akan tetapi sample yang digunakan adalah 16 orang atlet karena dari 20 atlet hanya 16 atlet yang dibawa untuk mengikuti kejuaraan Cisadane Internasional Dragon Boat Tournament 2019.

Subjek penelitian mengisi identitas singkat kemudian mengisi instrumen skala kecemasan dan skala peak performance. Skala yang digunakan adalah angket tertutup yang sudah disediakan jawabannya sehinga responden hanya diminta untuk memilih item-item yang disusun dalam bentuk pertanyaan. sangat sesuai (SS), sesuai (S), tidak sesuai (ST), dan sangat tidak sesuai (STS). Jenis pernyataan merupakan pernyataan positif dan negatif. Pada pernyataan bobot nilai untuk jawaban angat Sesuai $=4$, Sesuai $=$ 3 , Tidak Sesuai $=2$, Sangat Tidak Sesuai $=1$. Sedangkan pernytaan negatif dengan bobot nilai untuk jawaban Sangat Sesuai $=1$, Sesuai $=2$, Tidak Sesuai $=3$, Sangat Tidak Sesuai $=4$. (Sugiyono, 2017).

Teknik yang digunakan untuk menganalisis data dalam penelitian ini menggunakan statistik deskripi. Adapun penentuan kategorisasi dilakukan berdasarkan 
tingkat diferensiasi yang diketahui yaitu tinggi, sedang, dan rendah. Analisis data dalam penelitian ini dilakukan dengan menggunakan bantuan SPSS For Windows 22.0 Version.

\section{HASIL DAN PEMBAHASAN}

\section{Hasil}

Data kecemasan yang diperoleh disajikan kriteria kecendrungan yang ditentukan. Berikut ini merupakan data kecemasan pada atlet dayung Tradisional Boat Race (TBR) Club Dayung Three Generation.

\section{Tabel 1}

Data Kecemasan Atlet Dayung Tradisional Boat Race (TBR) Club Dayung Three Generation

\begin{tabular}{lllll}
\hline $\begin{array}{l}\mathrm{N} \\
\mathrm{o}\end{array}$ & $\begin{array}{l}\text { Kategori } \\
\text { sasi }\end{array}$ & $\begin{array}{l}\text { Rentan } \\
\text { skor }\end{array}$ & $\begin{array}{l}\text { frel } \\
\text { uen } \\
\text { si }\end{array}$ & $\begin{array}{l}\text { Persenta } \\
\text { si }\end{array}$ \\
\hline 1 & Tinggi & $>55$ & 2 & $12.5 \%$ \\
2 & Sedang & $35-22$ & 12 & $75.0 \%$ \\
3 & Rendah & $<35$ & 2 & $12.5 \%$ \\
& & jumlah & 16 & $100 \%$ \\
\hline
\end{tabular}

Berdasarkan table diatas dapat diketahui bahwa kecemasan atlet dayung Tradisional Boat Race (TBR) Club Dayung Three Generation berada pada kategori sedang.

Data peak performance diperoleh disajikan kriteria kecendrungan yang ditentukan. Berikut ini merupakan data kecemasan pada atlet dayung Tradisional Boat Race (TBR) Club Dayung Three Generation.

\section{Tabel 2}

\section{Data Peak Performance Atlet Dayung Tradisional Boat Race (TBR) Club Dayung}

\section{Three Generation}

\begin{tabular}{lllll}
\hline $\mathrm{N}$ & Kategori & $\begin{array}{l}\text { Rentan } \\
\text { skor }\end{array}$ & $\begin{array}{l}\text { frel } \\
\text { uen } \\
\text { si }\end{array}$ & $\begin{array}{l}\text { persenta } \\
\text { si }\end{array}$ \\
\hline 1 & Tinggi & $>89.8$ & 3 & $18.8 \%$ \\
2 & Sedang & $68.2-89.8$ & 11 & $68.8 \%$ \\
3 & Rendah & $<68.2$ & 2 & $12.5 \%$ \\
& & jumlah & 16 & $100 \%$ \\
\hline
\end{tabular}

Berdasarkan tabel diatas dapat diketahui atlet dayung Tradisional Boat Race (TBR) Club Dayung Three Generation berada pada kategori sedang.

Selanjutnya dilakukan uji analisis regresi sederhana untuk mengetahui linear sederhanan untuk mengetahui hubungan kecemasan terhadap performance. Hasil analisis SPSS Statistics Version 22.00 regresi dapat di sajikan pada table sebagai berikut:Setelah 
diketahui perhitungan nilai rata-rata dan simpangan baku dari masing-masing variabel, maka langkah selanjunya adalah melakukan pengujian normalitas. Pengujian normalitas dilakukan dengan menggunakan pendekatan uji kenormalan Liliefors yaitu uji non parametrik.

Table 3

\section{Analisis Regresi Hubungan Kecemasan Terhadap Performance}

\begin{tabular}{lcclc}
\hline \multicolumn{1}{c}{ Variable } & B & Beta & $\begin{array}{l}\text { R } \\
\text { Squer } \\
\mathrm{e} / \mathbf{R}^{2}\end{array}$ & Sig \\
\hline $\begin{array}{l}\text { Kecemas } \\
\text { an } \\
\text { bertanding } \\
- \text { Peak }\end{array}$ & 110,336 & $-0,688$ & 0,474 & 0,003 \\
$\begin{array}{l}\text { Performa } \\
\text { nce }\end{array}$ & & & & \\
\hline
\end{tabular}

Berdasarkan tabel diatas diperoleh nilai signifikasi sebesar 0,003. Hal ini dapat diartikan bahwa terdapat pengaaruh kecemasan terhadap peak performance. Pembuktian untuk hipotesis tersebut dapat dilihat dari nilai sugnifikasi yang diperoleh lebih kecil dari pada nilai probabilitas $0,005(0,003<0,005)$. Maka disimpulkan bahwa hipotesis terdapat pengaruh antara kecemasan terhadap peak performance atlet dayung Tradisional Boat Race (TBR) Club Dayung Three Generation. Sedangkan untuk nilai koefisien dertminasi sebesar 0,474 , maka dapat diartikan bahwa kontribusi yang diberikan kecemasan terhadap peak perormance sebesar $47.4 \%$ sedangkan $52,6 \%$ dipengaruhi oleh faktor lain. Pada tabel diatas juga digunakan untuk mengetahui hasil ppersamaan analisis regresi sederhana pada penelitian ini sebagai berikut:

$$
\begin{aligned}
& Y=a=b x \\
& Y=110,336+-0,688
\end{aligned}
$$

Berdasarkan table perhitungan SPSSfor Windows diatas, persamaan diatas menunjukan:

1. Nilai konstan 110,336 (a) yang berarti bahwa jika tidak ada kecemasan maka nilai peak performance atlet dayung Tradisional Boat Race (TBR) Three Generation sebesar 110,336.

2. Nilai koefisien regresi (b) variabel kecemasan sebesar -0,688 yang bernilai negatif menunjukan bahwa kecemasan mempunyai pengaruh negatif terhadap performance. Hal ini diartikan bahwa setiap meningkat 1 nilai kecemasan atlet dayung Tradisional Boat Race (TBR) Club Dayung Three Generation, maka nilai peak performance menurun sebesar 0.688 . 


\section{Pembahasan}

Kecemasan adalah kondisi emosi negatif seorang atlet yang ditandai dengan munculnya perasaaan khawatir, ragu-ragu, hilangnya kepercayaan diri, dan disertai dengan peningkatan sistem kebutuhan selama bertanding (Komarudin, 2014).

Dalam penelitian ini diperoleh hasil sesuai dengan rumusan masalah serta tujuan penelitian yang sudah diulas dalam bab sebelumnya. Tingkat kecemasan menggunakan kategori tinggi, sedang dan rendah. Berdasarkan hasil paparan uji deskriptif dan analisis yang dilakukan akan dapat diketahui bahwa subjek yang berada pada tingkat kategori kecemassan bertanding tinggi memiliki persentase sebesar $12.5 \%$ dengan frekuensi sebanyak 2 orang, subjek yang berada pada kategori sedang memiliki persentase $75 \%$ dengan frekuensi sebanyak 12 orang, subjek yang berada kecemasan rendah memiliki persentase sebesar $12.5 \%$ dengan frekuensi 2 orang.Hasil analisis tersebut menunjukan bahwa persentase kecemasan atlet dayung Tradisional Boat Race (TBR) Club Dayung Three Generation berada pada kategori sedang yaitu $75 \%$ dengan sebanyak 12 orang. Dari hasil ini diketahui bahwa rata-rata tingkat kecemasan atlet pada kategori sedang. Ini menandakan bahwa sebagian besa atlet dayung Tradisional Boat Race (TBR) Club Dayung Three Generation memikirkan hal-hal yang tidak dikehendaki akan terjadi pada saat pertandingan sehingga akan mengganggu saat pertandingan. Hal ini diperkuat oleh (Wang, 2010) dalam jurnalnya yang berjudul "Olympic CoachingPsychology: Winning Strategies for All Athletes" yang menjelaskan bahwa pikiran negatif yang berasal dari dalam diri atlet dapat mengakibatkan atlet tampil buruk. Kecemasan yang melanda atlet dayung Tradisional Boat Race (TBR) Club Dayung Three Generation tersebut menjadi salah satu faktor yang memperngaruhi penampilannya sehingga mengganggu atlet dayung Tradisional Boat Race (TBR) Club Dayung Three Generation menuju performance terbaiknya. Menurut Weinberg dan Gould kecemasan merupakan sebuah perassaan negatif yang memiliki ciri gugup, rasa gelisah, ketakutan akan sesuatu yang belum terjadi, dan yang terjadi pergerakan atau kegaiahan dalam tubuh (Rohmansyah 2017) .

Dalam penelitian ini diperoleh beberapa hasil dengan rumusan masalah serta tujuan penelitian yang telah diulas dalam bab sebelumnya. Tingkat performance menggunakan kategori tinggi, sedang dan rendah. Berdasarkan hasil paparan uji deskriptif dan analisis yang dilakukan maka dapat diketahui bahwa subjek yang berada pada tingkat kategori performance tinggi memiliki persentase $18 \%$ dengan frekuensi 3 orang, subjek yang berada pada kategori performance sedang memiliki persentase $68.8 \%$ 
dengan frekuensi sebanyak 11 orang, subjek yang berada pada kategori performance rendah memiliki persentase $12.5 \%$ dengan frekuensi sebanyak 2 orang.

Hasil analisis menunjukan bahwa persentase performance atlet dayung Tradisional Boat Race (TBR) Club Dayung Three Generation. berada pada kategori sedang. yaitu $68.8 \%$ dengan sebanyak 11 orang. Dari hal ini diketahui bahawa tingkat performance atlet rata-rata berada pada kategori sedang. Ini menandakan bahwa sebagian besar atlet dayung Tradisional Boat Race (TBR) Club Dayung Three Generation tidak terpengaruh dengan kecemasan bertanding dan sudah bisa mengendalikan mental dan fisik mereka dengan baik. Menurut Vikki \& Jean M (Fakhrurri, 2018) "Peak Performance adalah kejadian saat atlet melakukan performance terbaik dengan menggabungkan fisik dan mental pada atlet".

Berdasarkan hasil analisis regresi menunjukan bahwa kecemasan memiliki hubungan terhadap performance atlet dayung Tradisional Boat Race (TBR) Club Dayung Three Generation. Sehingga dengan demikian hipotesis yang menyatakan bahwa terdapat hubungan tingkat kecemasan terhadap performance atlet dayung Tradisional Boat Race (TBR) Club Dayung Three Generation diterima.

Berdasarkan hasil analisi dengan menggunkan SPSS dengan model summary menunjukan hasil $\mathrm{R}$ squer sebesar 0,474 yang berarti besar hubungan kecemasan adalah 47,4\%. Jika dilihat dari persentase terbilang cukup besar hubunganya, karena 52,6\% dipengaruhi oleh faktor lain. Nilai korelasi (Rxy) antara variable kecemasan dengan performance sebesar $-0,688$. Selain itu nilai signifikasi kecemasan terhadap performance sebesar 0,003, nilai ini lebih kecil dibandingkan dengan nilai 0,05. Hal tersebut dapat diartikan bahwa setianp meningkatnya 1 nilai kecemasan atlet dayung Tradisional Boat Race (TBR) club dayung three generation akan menurun sebesar 0, 689. Menurut Haruki "salah satu faktor yang menyebabkan peak performence adalah faktor yang berhubungan dengan atlet yaitu kecemasan bertanding".

\section{KESIMPULAN}

Berdasarkan hasil penelitian pada hubungan variable bebas terhadap variable terikat terdapat hubungan yang signifikan antara kecemasan terhadap performance. Hubungan antara kecemasan terhadap performance adalah sebesar negatif 0,689 , hal ini berarti bahwa semakin tinggi kecemasan atlet dayung maka performance akan semakin rendah dan begitu juga sebaliknya, semakin rendah kecemasan maka semakin tinggi performance. Keakuratan kecemasan terhadap performance ini adalah sebesar $47.4 \%$ dan sisanya $52,6 \%$ dipengaruhi oleh faktor lain. 


\section{DAFTAR PUSTAKA}

Arikunto, Suharsimi. (2010). Manajemen Penelitian. Jakarta: Rineka Cipta.

Fakhrurri, M.I. (2018). Pengaruh Kecemasan Bertanding Terhadap Peak Performance Atlet bola Basket Universitas Islam Maulana Malik Ibrahim”. Skripsi, Falkultas Psikkologi Universitas Islam Maulana Malik Ibrahim.

Fitri, Annisa Dona. (2016). Konsep Kecemasan (anxiety) Pada Lanjut Usia (lansia). Jurnal Konselor Volume 5. Universitas Negeri Padang.

Gunarsa, S.D. (2008). Psikologi Olahraga Prestasi. Jakarta: PT BPK Gunung Mulia.

Husdarta, H. J. S,.(2010). Psikologi Olahraga. Bandung: Alfabeta.

Komarudin. (2014). Psikologi Olahraga. Bandung: PT Remaja Rosdakarya.

Miftah, F. (2016). Pengaruh kecemasan bertanding terhadap peak performancence pada atlet softball Universitas Negeri Yogyakarta. E-Jurnal Universita Negeri Yogyakarta.

Rohmansyah, N, A. (2017). Kecemasan dalam Olahraga. Jurnal Ilmiah Penjas Volume 3(1). Universitas PGRI Semarang.

Sugiyono. (2017). Metode Penelitian Kuantitatif Kualitatif $R \& D$. Bandung: ALFABETA

Wang, By Jin. (2010). Olympic Coaching Psychology: Winning Strategies or All Athletes. Soccer Journal January-Februari 2010.

Zuzana, Melly. (2015). Kontribusi daya tahan kekuatan otot lengan dan kelentukan terhadap kemampuan mendayung jarak 500 meter atlet dayung kabupaten padang pariaman. Universitas Negeri Padang. 